\title{
PERAN PENDIDIKAN IN-FORMAL DALAM MENDIDIK ANAK PADA KELUARGA BROKEN HOME DI KELURAHAN BUKIT LAMA KOTA PALEMBANG
}

\author{
Gamar Septianita, Abdurrahmansyah, Muhammad Fauzi \\ UIN Raden Fatah Palembang \\ Email:Septianita20@gmail.com
}

\begin{abstract}
ABSTRAK
Judul Penelitian ini "peran pendidikan In-formal dalam mendidik anak pada keluarga broken home di Kelurahan Bukit Lama Palembang" Berdasarkan hasil observasi, Kurangnya perhatian orang tua terhadap anak terlihat orang tua yang selalu sibuk dalam melaksanakan pekerjaannya, Kurangnya pengawasan orang tua dalam pergaulan anak, Tidak adanya tanggung jawab orang tua terhadap anak terlihat dari pendidikan orang tua yang hanya tamatan Sekolah Dasar (SD) sehingga pemahamannya tentang cara mendidik anaknya kurang baik, Hilangnya kehangatan antara orang tua dan anak, kurangnya komunikasi diantara anggota keluarga menyebabkan hilangnya kehangatan didalam keluarga antara orang tua dan anak, Kebutuhan yang belum terpenuhi yang membuat orang tua sering terjadinya perbedaan pendapat dengan anak.

Dengan masalah Bagaimana peran pendidikan In-formal dalam mendidik anak pada keluarga broken home di Kelurahan Bukit Lama Kota Palembang?, Apa faktor-faktor yang mempengaruhi keluarga broken home di Kelurahan Bukit Lama Kota Palembang ?, Bagaimana upaya untuk mengatasi keluarga broken home di Kelurahan Bukit Lama Kota Palembang ?. Maka tujuanya untuk mengetahui peran pendidikan In-formal dalam mendidik anak pada keluarga broken home di Kelurahan Bukit Lama Kota Palembang, untuk mengetahui faktor-faktor yang mempengaruhi keluarga broken home di Kelurahan Bukit Lama Kota Palembang, untuk mengetahui upaya mengatasi keluarga broken home di Kelurahan Bukit Lama Kota Palembang.

Penelitian ini merupakan penelitian deskriptif kualitatif yaitu mendeskripsikan fakta di lapangan, Sumber data sekunder yaitu data penunjang di dalam penelitian ini, seperti buku-buku, internet, serta bahan kepustakaan lain yang ada relevensinya dengan penelitian ini, maka peneliti menggunakan alat pengumpul data yang berupa observasi, wawancara mendalam dan dokumentasi. Sumber data (informan) meliputi data primer dan data sekunder yaitu data yang didapatkan langsung dari sumber data melalui informan yaitu orang tua (yang mengalami keluarga broken home) dan anak usia 6-12 tahun (yang menjadi korban keluarga broken home). Hasil dari penelitian yang peneliti lakukan, yaitu mendidik anak pada keluarga broken home di Kelurahan Bukit Lama Palembang ialah orang tua menjadi suri tauladan yang baik, orang tua sebagai pendidik, orang tua sebagai pembimbing, orang tua sebagai pengawas, dan orang tua sebagai motivasi
\end{abstract}

Keywords: Pendidikan In-formal, Broken Home 


\section{PENDAHULUAN}

Pendidikan tidak dapat dipisahkan dari tiga hal yaitu keluarga, sekolah, dan lingkungan masyarakat. Keberhasilan pendidikan pada suatu negara atau daerah tergantung kepada tiga faktor tersebut. Dalam arti sederhana pendidikan sering diartikan sebagai usaha manusia untuk membina kepribadiannya sesuai dengan nilai-nilai di dalam masyarakat dan kebudayaan. Perkembangan ilmu pengetahuan dan teknologi, khususnya informasi, para ahli pendidikan di berbagai negara sangat cemas terhadap pengaruh ilmu dan teknologi terhadap pembentukan akhlak generasi muda. Untuk mengatasi tantangan tersebut, perlu adanya pembinaan dan tannggung jawab secara simulitas antara tiga lembaga yaitu, lembaga In-formal, formal, dan non-Formal.

Keluarga dan pendidikan adalah dua istilah yang tidak bisa dipisahkan, sebab dimana ada keluarga di situ ada pendidikan. Dimana ada orang tua disitu ada anak yang merupakan suatu kemestian dalam keluarga. ketika ada orang tua yang ingin mendidik anaknya, maka pada waktu yang sama ada pertanggung jawaban orang tua terhadap anaknya. sini muncullah istilah "pendidikan In-formal". Artinya pendidikan In-Formal adalah pendidikan yang berlangsung ditengah keluarga yang dilaksanakan oleh orang tua sebagai tugas dan tanggung jawabnya dalam mendidik anak dalam sebuah keluarga. ${ }^{1}$ In-formal terutama berlangsung di tengah keluarga. Keluarga adalah kesatuan sosial terkecil yang dimiliki manusia yang bertempat tinggal dan ditandai oleh adanya kerjasama ekonomi, mendidik, melindungi dan sebagainya. Penanaman nilai-nilai Ilahiyah dilakukan terutama di rumah oleh orang tua anak. Orang tua adalah pendidik utama dan yang paling utama. Mengapa demikian, karena pengaruh orang tua terhadap perkembangan anak amat mendalam dalam perkembangan kepribadian anak, pertama karena orang tua adalah orang yang pertama dan paling utama melakukan kontak langsung dengan anak. ${ }^{2}$

Keluarga diartikan sebagai suatu sosial terkecil yang dimiliki sebagai makhluk sosial, yang ditandai adanya kerja sama ekonomi. Fungsi keluarga adalah berkembang biak, mensosialisasi atau mendidik anak, menolong, melindungi atau merawat orang-orang tua. Bentuk keluarga terdiri dari seorang suami, seorang istri, dan anak-anak yang biasanya tinggal dalam satu rumah yang sama (disebut keluarga inti). Anak merupakan simbol berbagai macam hubungan peran yang penting diantara orang-orang dewasa. Adanya kemesraan antara orang tua dan kehadirannya terus-menerus, menimbulkan tuntutan-tuntutan kepada berbagai orang dewasa. Orang-orang dewasa ini pun mengadakan tuntutan satu dengan yang lainnya karena anak.

Keluarga yang utuh adalah keluarga yang dilengkapi dengan anggotaanggota keluarga seperti, ayah, ibu dan anak-anak. Sebaliknya keluarga yang pecah atau broken home terjadi dimana tidak hadirnya orang tua karena kematian atau perceraian, atau tidak hadirnya kedua-duanya. Antara keluarga yang utuh dan yang pecah mempunyai pengaruh yang berbeda terhadap perkembangan anak. Keluarga yang utuh tidak sekedar utuh dalam dalam arti berkumpulnya ayah dan ibu tetapi utuh dalam arti yang sebenar-benarnya yaitu disamping utuh dalam fisik juga utuh dalam psikis. keluarga yang utuh memiliki perhatian yang penuh atau tugastugasnya sebagai orang tua. Sebaliknya keluarga yang pecah atau broken home

${ }^{1}$ Syaiful Bahri Djamarah, Pola Asuh Orang Tua Dan Komunikasi Keluarga, (Jakarta:Rineka Cipta, 2014), Hlm. 02

${ }^{2}$ Rusmaini, Ilmu Pendidikan, (Palembang: Grafika Telindo Press, 2014), Hlm. 43 
perhatian terhadap anaknya kurang antara ayah dan ibu tidak memiliki kesatuan perhatian atas anak-anaknya. Broken home memiliki pengaruh yang negatif. Situasi keluarga yang broken home tidak menguntungkan bagi perkembangan anak. ${ }^{3}$

Proses pendidikan dalam keluarga merupakan tonggak awal keberhasilan proses pendidikan selanjutnya, baik di sekolah maupun dalam lingkungan masyakarat. Demikian pula sebaiknya, kegagalan pendidikan keluarga akan berdampak pula pada keberhasilan proses pendidikan anak selanjutnya. Berdasarkan Hasil wawancara sementara dengan Bapak Doni Marianto, A.Md. (Pegawai kelurahan bagian pelayanan umum) pada tanggal 03 Januari 2018 diperoleh informasi bahwa dari 75 rukun tetangga (RT) dengan jumlah penduduk 43.103 ribu jiwa yang bertempat tinggal di wilayah Kelurahan Bukit Lama Palembang, yang paling banyak jumlah kepala keluarganya ialah warga di Jalan Tanjung Rawo RT 55 Rw 16 Kelurahan Bukit Lama Palembang. Dengan jumlah kepala keluarga 130 kepala keluarga. Dalam hal ini peneliti mengambil warga terbanyak yang ada di wilayah Kelurahan Bukit Lama Palembang untuk diteliti yaitu diwilayah Jalan Tanjung Rawo Rt $55 \mathrm{Rw} 16$ Kelurahan Bukit Lama Palembang.

Dari gambaran di atas, maka penulis tertarik melakukan penelitian mengenai Peran Pendidikan In-Formal Dalam Mendidik Anak Pada Keluarga Broken Home Di Kelurahan Bukit Lama Kota Palembang. Berangkat dari latar belakang dan identifikasi masalah di atas, maka rumusan masalah yang akan dibahas dalam penelitian ini adalah sebagai berikut: Bagaimana peran pendidikan In-formal dalam mendidik anak pada keluarga broken home di Kelurahan Bukit Lama Kota Palembang?

\section{METODE PENELITIAN}

Penelitian ini menggunakan jenis penelitian lapangan (field research). Menurut Lexy J. Moleong, field research dianggap sebagai pendekatan luas dalam penelitian kualitatif atau sebagai metode untuk mengumpulkan data kualitatif. Ide pentingnya adalah bahwa peneliti berangkat kelapangan untuk mengadakan pengamatan tentang suatu fenomena dalam suatu keadaan alamiah. Peneliti lapangan biasanya membuat catatan lapangan secara ekstensif yang kemudian diorganisasikan serta menganalisis data tentang kasus-kasus tertentu berkenaan dengan permasalahan-permasalahan yang menjadi perhatian peneliti.

Penelitian ini diharapkan dapat memberi gambaran tentang peran pendidikan In-Formal dalam mendidik anak pada keluarga broken home di Kelurahan Bukit Lama Palembang. Lebih tepatnya di wilayah Jalan Tanjung Rawo Rt 55 Rw 16 Kelurahan Bukit Lama Palembang sebagai pokok bahasan penelitian ini.

\section{HASIL PENELITIAN}

Setiap orang tua menginginkan anaknya menjadi orang yang berkembang secara sempurna. Anak adalah aset yang amat berharga bagi orang tua sekaligus investasi nyata di masa mendatang. Anak juga merupakan pribadi yang masih bersih dan peka terhadap rangsangan-rangsangan yang berasal dari lingkungan.

${ }^{3}$ Abu Ahmadi, Psikologi Sosial, (Jakarta: PT Rineka Cipta, 2009), Hlm. 229- 
Selain itu anak merupakan bagian dari keluarga dan keluarga memberi kesempatan bagi anak untuk belajar berbagai sesuatu yang baik yang sudah diajarkan orang tua kepada anak untuk perkembangan anak agar menjadi lebih baik. Setiap perkembangan anak memiliki keunikan tersendiri, dan disinilah peran orang tua, pendidik, serta lingkungan masyarakat untuk memahami setiap keunikan dari tahapan perkembangan seorang anak. Dengan pemahaman demikian, diharapkan dapat menjadi pijakan bagi orang tua maupun para pendidik dalam membimbing dan mendidik anak-anak secara lebih baik.

Penelitian ini dilakukan di Keluarga yang mengalami Broken Home yang berlokasi di Jalan Tanjung Rt 55 Rw 16 Kelurahan Bukit Lama Palembang. pada penelitian ini peneliti meneliti 10 orang informan yang terdiri dari 5 orang tua yang mengalami keluarga broken home dan 5 anak usia 6-12 tahun yang menjadi korban keluarga broken home. Adapaun informan dalam penelitian ini ialah sebagai berikut:

\section{Tabel 4.1}

Nama-Nama Informan Penelitian

\begin{tabular}{|c|l|l|}
\hline No. & Nama-Nama Informan & Sebagai \\
\hline 1. & Ibu Elly & $\begin{array}{l}\text { Orang tua yang mengalami keluarga } \\
\text { broken home }\end{array}$ \\
\hline 2. & Ibu Aci & $\begin{array}{l}\text { Orang tua yang mengalami keluarga } \\
\text { broken home }\end{array}$ \\
\hline 3. & Ibu Lehak & $\begin{array}{l}\text { Orang tua yang mengalami keluarga } \\
\text { broken home }\end{array}$ \\
\hline 5. & Ibu Endang & $\begin{array}{l}\text { Orang tua yang mengalami keluarga } \\
\text { broken home }\end{array}$ \\
\hline 6. & Anharrudin & $\begin{array}{l}\text { Orang tua yang mengalami keluarga } \\
\text { broken home }\end{array}$ \\
\hline 7. & Jaya & $\begin{array}{l}\text { Anak usia 12 tahun yang menjadi } \\
\text { korban keluarga broken home }\end{array}$ \\
\hline 8. & Dilla & $\begin{array}{l}\text { Anak usia 7 tahun yang menjadi } \\
\text { korban keluarga broken home }\end{array}$ \\
\hline 9. & Putri & $\begin{array}{l}\text { Anak usia 11 tahun yang menjadi } \\
\text { korban keluarga broken home }\end{array}$ \\
\hline 10. & Neni & $\begin{array}{l}\text { Anak usia 6 tahun yang menjadi } \\
\text { korban keluarga broken home }\end{array}$ \\
\hline & & $\begin{array}{l}\text { Anak usia 10 tahun yang menjadi } \\
\text { korban keluarga broken home }\end{array}$ \\
\hline
\end{tabular}

Penelitian ini dilakukan peneliti pada keluarga yang mengalami broken home di Jalan Tanjung Rawo Rt 55 Rw 16 Keluarahan Bukit Lama Palembang dari tanggal 2 Juli 2018 sampai pada tanggal 2 September 2018 terlihat Kurangnya perhatian orang tua terhadap anak terlihat orang tua yang selalu sibuk dalam melaksanakan pekerjaannya, kurangnya pengawasan orang tua dalam pergaulan anak, tidak adanya tanggung jawab orang tua terhadap anak terlihat dari pendidikan orang tua yang hanya tamatan Sekolah Dasar (SD) sehingga pemahamannya tentang cara mendidik anaknya kurang baik, hilangnya kehangatan antara orang tua 
dan anak, kurangnya komunikasi diantara anggota keluarga menyebabkan hilangnya kehangatan didalam keluarga antara orang tua dan anak, serta kebutuhan yang belum terpenuhi dengan baik yang menyebabkan orang tua sering mengalami perbedaan pendapat terhadap anak.

Analisis data yang Dilakukan dalam bab ini adalah mengenai bagaimana peran pendidikan In-formal dalam mendidik anak pada keluarga broken home, rumusan masalah kedua, faktor apa saja yang mempengaruhi keluarga broken home, dan rumusan masalah ketiga, upaya apa saja untuk mengatasi keluarga broken home. Kemudian peneliti membuat pedoman wawancara, setelah itu peneliti mengajukan pertanyaan kepada orang tua dan anak pada keluarga broken home yang memiliki usia 6-12 tahun. Dalam hal ini, peneliti menganalisi data yang telah diperoleh berdasarkan hasil observasi, wawancara mendalam dan dokumentasi, dimulai dari mereduksi data (merangkum data, memilih hal-hal pokok dan memfokuskan pada hal-hal yang penting), selanjutnya penyajian data teks yang bersifat naratif, kemudian langkah selanjutnya yaitu penarikan kesimpulan dan verifikasi data.

\section{A. Peran Pendidikan Keluarga (In-Formal) Dalam Mendidik Anak Pada Keluarga Broken Home}

Keluarga merupakan tempat pendidikan pertama dan utama bagi seseorang. Pendidikan dalam keluarga sangat berperan dalam mengembangkan watak, karakter dan kepribadian seseorang. Keluarga adalah orang-orang yang berada dalam seisi rumah yang sekurang-kurangnya terdiri dari suami, istri, dan anak-anak. Keluarga diartikan dengan satuan kekerabatan yang sangat mendasar dalam masyarakat. biasanya terdiri dari ibu, bapak, dengan anak-anak atau orang yang seisi rumah yang menjadi tanggung jawabnya. ${ }^{4}$

Pendidikan keluarga merupakan pendidikan yang sesungguhnya, karena di dalam lingkungan keluargalah seorang anak memulai proses belajar. Belajar dalam pengertian sebenarnya, yaitu anak-anak mulai diajak mengenal diri dan lingkungannya secara aktif dan intensif. Dalam hal ini kedua orang tua memiliki peranan menentukan bagi perkembangan dan pembentukan mentalitas anak selanjutnya. Dan berdasarkan hasil penelitian di lapangan ada beberapa aspek peran pendidikan keluarga (In-formal) dalam mendidik anak pada keluarga broken home, yang diteliti dalam penelitian ini meliputi:

\section{Orang Tua Sebagai Suri Tauladan Yang Baik}

Peran orang tua sebagai suri tauladan yang baik, menurut Sri Lestari dalam bukunya psikologi keluarga mengatakan orang tua sebagai teladan adalah orang tua melakukan terlebih dahulu perilakuperilaku yang mengandung nilai-nilai moral yang akan disampaikan kepada anak. Dengan demikian, ketika orang tua menyampaikan pesan nilai moral pada anak, orang tua dapat menunjuk pada perilaku-perilaku

\footnotetext{
${ }^{4}$ Amirulloh Syarbini, Model Pendidikan Karakter Dalam Keluarga, (Jakarta: Pt. Elex Media Komputindo, 2014), Hlm. 19
} 
yang telah di contohkan,dimana sesuatu yang patut dan ditiru atau baik untuk dicontoh. ${ }^{5}$

Dengan demikian keteladanan orang tua adalah suatu perbuatan atau tingkah laku baik, yang patut ditiru oleh anak-anak yang dilakukan oleh orang tua di dalam tugasnya. Orang tua juga merupakan pengukir dalam kepribadian anak, sebelum mendidik orang lain, sebaiknya orang tua harus mendidik pada dirinya terlebih dahulu, sebab anak merupakan peniru, segala informasi yang masuk pada diri anak, baik melalui penglihatan ataupun pendengaran dari orang di sekitarnya termasuk orang tua akan membentuk karakter anak tersebut.

Hal ini disampaikan oleh ibu Aci melalui wawancara yang peneliti lakukan, beliau mengatakan:

"Peran saya sebagai suri tauladan yang baik bagi anak saya ialah saya mencontohkan anak saya shalat dengan cara terlebih dahulu saya yang mengerjakan shalat dengan seperti itu anak saya akan ikut mengerjakan shalat". 6

Senada dengan yang dikemukakan ibu Aci, ibu Elly mengatakan : "Saya sebagai suri tauladan yang baik untuk anak saya ialah saya selalu berkata lemah lembut terhadap anak saya dan tidak pernah berkata kotor dihadapan anak saya ketika saya sedang marah".

Berbeda halnya yang dikemukakan oleh ibu Aci dan ibu Elly, ibu Lehak mengatakan :

"Sebagai suri tauladan yang baik saya mencontohkan kepada anak saya untuk saling memberi kepada orang lain dan anak saya sering melihat saya bahkan sering saya perintahkan untuk memberi makanan ketetangga ketika saya membuatan makanan lebih di rumah". ${ }^{8}$

Sebagaimana yang dikemukakan oleh orang tua terhadap orang tua sebagai suri tauladan yang baik untuk anak, Jaya anak ibu Aci mengatakan:

"Saya sering melihat ibu melakukan shalat di rumah ketika ibu saya pulang dari pekerjaannya dan saya melakukan hal yang sama ketika ibu saya mengingatkan saya untuk melakukan shalat". 9

Senada yang dikemukakan oleh Jaya, Anharrudin anak ibu Elly pun mengatakan :

"Ketika saya meminta paksa uang jajan saat orang tua saya baru pulang bekerja, orang tua saya sering marah kepada saya tetapi marah orang tua saya tidak pernah saya mendengarkan orang tua saya mengeluarkan perkataan kotor kepada saya bahkan ketika saya meminta uang jajan mama saya selalu berkata lemah lembut kepada

${ }^{5}$ Sri Lestari, Psikologi Keluarga, (Jakarta: Kencana, 2012), Hlm. 162

${ }^{6}$ Aci, Orang Tua Yang Mengalami Keluarga Broken Home, Wawancara, 27 Agustus 2018

${ }^{7}$ Elly, Orang Tua Yang Mengalami Keluarga Broken Home, Wawancara, 25 Agustus 2018

${ }^{8}$ Lehak, Orang Tua Yang Mengalami Keluarga Broken Home, Wawancara, 31 Agustus 2018

${ }^{9}$ Jaya, Anak Korban Keluarga Broken Home, Wawancara, 27-28 Agustus 2018 
saya dan mensehati saya agar bersabar dan berkata sopan ketika orang tua baru sampai di rumah dan baru pulang bekerja. dan akhirnya saya terbiasa dan tidak mengulangi hal yang sama ketika orang tua saya baru pulang bekerja saya pun harus bersabar dan membiarkan orang tua saya beristirahat terlebih dahulu". ${ }^{10}$

Berdasarkan hasil observasi yang telah peneliti lakukan di lapangan pada keluarga broken home di Jalan Tanjung Rawo Rt 55 Rw 16 Kelurahan Bukit Lama Palembang. Bahwa orang tua yang sudah memberikan keteladanan yang baik kepada anaknya dengan cara orang tua terlebih dahulu mencontohkan untuk melakukan hal yang membuat anak untuk menirunya seperti anak terbiasa melihat orang tua melaksanakn shalat, mengaji, dan saling membantu kepada sesama. Pada intinya semua sama, memberikan contoh terlebih dahulu karena anak lebih cenderung meniru suatu perbuatan dibandingkan melakukan apa yang diperintahkan. ${ }^{11}$

Berdasarkan observasi dan wawancara di atas dapat dianalisis bahwa teladan yang baik dari orang tua akan berpengaruh besar terhadap perkembangan anak di masa yang akan datang, orang tua dalam memberikan teladan harus sesuai dengan perkembangan anaknya sehingga anak mudah mencerna apa yang disampaikan oleh orang tuanya. Akan tetapi kalau orang tua tidak bisa mencontohkan teladan yang baik terhadap anak maka anak pun tidak mau melakukan apa yang dilakukan oleh orang tuanya.

\section{Orang Tua Menjadi Pendidik}

Orang tua harus memahami kedudukannya sebagai pendidik yang sangat berperan dalam mendidik anaknya. Orang tua harus memahami tentang tahapan perkembangan anak agar dapat membentuk karakter anak secara lebih mudah. Anak adalah amanah yang harus dipertanggungjawabkan oleh orang tua terutama dalam hal pendidikannya. ${ }^{12}$ Setiap orang tua harus memahami perkembangan anak berdasarkan usia dan karakteristik yang dimiliki anak. Hal tersebut berkaitan dengan pengajaran yang dapat diterima oleh anak dan akan berbeda pada tingkatan usianya.

Hal ini disampaikan oleh ibu Elly melalui wawancara yang peneliti lakukan, beliau mengatakan :

"Didikan saya untuk anak keras, misalkan dalam bermain harus milih teman terus kemana pergi harus tau, dan dinasehati jangan sering ikut-

\footnotetext{
${ }^{10}$ Anharrudin, Anak Korban Keluarga Broken Home, Wawancara, 26 Agustus 2018

11 Observasi Lapangan, Keluarga Broken Home Di Jalan Tanjung Rawo Rt 55 Rw 16 Kelurahan Bukit Lama Palembang, 2 Juli-23 Agustus 2018

12 Ridwan Abdullah Sani Dan Muhammad Kadri, Pendidikan Karakter, (Jakarta: PT. Bumi Aksara, 2016), Hlm. 212
} 
ikutan kerjaan temen yang tidak bener aturan yang saya buat di dalam rumah kalau pulang sekolah langsung pulang, magrib harus di rumah, ketika anak saya magrib belum pada kumpul di rumah maka saya sering mencubit dan memukul anak saya atas kesalahan yang dibuat oleh anaknya". 13

Senada yang dikemukakan ibu Elly, Ibu Lehak juga mengatakan : "jika aturan jelas ada waktu belajar harus belajar waktu main ya main waktu sekolah ya sekolah, main tidak boleh jauh-jauh dari rumah dan didikannya juga keras kalau tidak mau belajar dikurung di luar rumah tidak boleh masuk rumah, serta mengajarkan anak untuk bersikap sopan terhadap orang tua dan berkata jujur dalam kehidupan sehari-hari". ${ }^{14}$

Dalam hal ini Dilla anak ibu Lehak dan Anharrudin anak ibu Elly, mengatakan :

"cara orang tua saya mendidik saya dengan cara menasehati saya untuk mematuhi perkataan orang tua, tidak boleh membohongi orang tua, dan di sekolah harus mematuhi perintah guru serta tidak boleh nakal jika saya nakal atau tidak mematuhi perkataan orang tua saya biasanya saya dimarahi dan dipukul oleh orang tua saya". ${ }^{15}$

Berdasarkan hasil observasi yang peneliti lakukan di lapangan pada keluarga broken home di Jalan Tanjung Rawo Rt 55 Rw 16 Kelurahan Bukit Lama Palembang orang tua sebagai pendidik sudah melakukan perannya dengan baik, orang tua mendidik anaknya dengan memberikan pendidikan yang baik bagi anak dan mengajarkan anak untuk disiplin dalam segala hal bertanggung jawab dalam segala sesuatu yang harus anak lakukan setiap harinya. ${ }^{16}$

Dari hasil observasi dan wawancara yang telah peneliti lakukan di lapangan dapat dianalisis bahwa setiap orang tua harus memahami perkembangan anak berdasarkan usia dan karakteristik yang dimiliki anak. Hal tersebut berkaitan dengan pengajaran yang dapat diterima oleh anak akan berbeda pada tingkatan usia serta bervariasi tergantung pada perkembangan anak. Pada anak usia 6-12 tahun merupakan usia yang amat kritis dan penting dalam perkembangan anak. Pada usia ini, apa pun yang dilihat dan didengar anak mempunyai pengaruh yang sangat mendalam dalam pembentukan pribadinya. Hal tersebut menyebabkan apa yang terekam dalam benak anak akan memiliki pengaruh yang signifikan dalam membentuk kepribadiannya ketika dewasa. Oleh sebab itu, pada usia 6-12 tahun orang tua harus

\footnotetext{
${ }^{13}$ Elly, Orang Tua Yang Mengalami Keluarga Broken Home, Wawancara, 25 Agustus 2018

${ }^{14}$ Lehak, Orang Tua Yang Mengalami Keluarga Broken Home, Wawancara, 31 Agustus 2018

${ }^{15}$ Dilla, Anak Korban Keluarga Broken Home, Wawancara, 31 Agustus 2018

${ }^{16}$ Observasi Lapangan, Keluarga Broken Home Di Jalan Tanjung Rawo Rt 55 Rw 16 Kelurahan Bukit Lama Palembang, 2 Juli-23 Agustus 2018
} 
memberikan banyak perhatian kepada anak terutama dalam pendidikannya

\section{Orang Tua Sebagai Pembimbing}

Orang tua memegang peranan penting untuk mendidik dan membimbing anak dengan memberikan bimbingan dan latihan bagaimana belajar dengan benar, juga strategi belajar yang tepat. Serta orang tua sangat penting dalam mendidik dan mengembangkan kemampuan anak, sekolah, pada dasarnya mengarahkan, memberikan bimbingan dengan kerangka bagi anak untuk belajar, bertumbuh dan berkembang. Sementara orang tua adalah pusat pendidikan yang utama, pertama dan mendasar dalam kehidupan anak. ${ }^{17}$

Peran orang tua sebagai pembimbing, dalam membimbing anak, orang tua perlu memiliki kesabaran dan sikap yang bijaksana, orang tua harus memahami alam pikiran anak dan harus mengerti kemampuan yang dimiliki anak. Hal ini disampaikan oleh bapak Ninu melalui wawancara yang peneliti lakukan, beliau mengatakan :

"saya sesekali membimbing anak saya dengan cara mendampinginya saat anak saya sedang belajar di rumah, ketika saya menemani anak saya belajar saya juga menanyakan kesulitan anak saya saat mengerjakan tugasnya dan ketika anak mengalami kesulitan belajar makan akan meminta bantuan saya untuk mengatasi masalah kesulitan dalam mengerjakan tugasnya dari sekolah". ${ }^{18}$

Lain halnya yang dikemu

kakan oleh bapak Ninu, Ibu Aci mengatakan :

"caranya tetap memberikan bimbingan kepada anak, walaupun kehilangan keharmonisan saya kepada ayahnya tetap memberikan akhlak yang baik kepada anak. Tidak memberikan contoh yang buruk kepada anak. Memberikan bimbingan kepada anak agar selalu dekat kepada Allah dan orang tua. Seperti membimbing anak untuk beribadah kepada Allah, membantu anak untu belajar mengaji selain dapat pelajaran yang sudah ia dapatkan di tempatnya mengaji, dan selalu memberikan nasihat agar selalu mematuhi kedua orang tuanya". ${ }^{19}$

Begitupun ibu Lehak, mengatakan:

"Saya belum bisa memberikan bimbingan yang baik kepada anak saya. Karena anak saya masih sering membatah, melanggar, melawan apa yang saya katakan kepada anak saya". ${ }^{20}$

\footnotetext{
${ }^{17}$ Chairinniza Graha, Keberhasilan Anak Tergantung Orang Tua, (Jakarta: Pt. Elex Media Komputindo, 2007), Hlm. 98

${ }^{18}$ Ninu, Orang Tua Yang Mengalami Keluarga Broken Home, Wawancara, 2 September 2018

${ }^{19}$ Aci, Orang Tua Yang Mengalami Keluarga Broken Home, Wawancara, 27 Agustus 2018

${ }^{20}$ Lehak, Orang Tua Yang Mengalami Keluarga Broken Home, Wawancara, 31 Agustus 2018
} 
Terdapat perbedaan yang kemukakan oleh ibu Lehak, Dilla putri ibu Lehak, mengatakan :

"orang tua saya membimbing saya dengan mengajarkan saya shalat, mengajarkan saya nulis, mengajarkan saya mengaji di rumah tetapi ketika saya diperintahkan dan memaksa saya melakukannya saya sering tidak mematuhi perkataan ibu saya sehingga saya sering dimarahi oleh ibu". 21

Berdasarkan hasil observasi yang peneliti lakukan di lapangan pada keluarga broken home di Jalan Tanjung Rawo Rt 55 Rw 16 Kelurahan Bukit Lama Palembang tidak jauh berbeda yang dikemukakan oleh informan, orang tua sebagai pembimbing telah melakukan perannya sudah cukup baik walaupun ada sebagian orang tua yang belum menjalankan perannya dengan baik karena ada anak yang selalu membantah dengan omongan orang tua dan nakal. Ada juga sebagaian orang tua yang telah menjalankan perannya dengan baik dengan cara menanamkan nilai-nilai agama pada anak dan memperhatikan dalam pendidikan anak. ${ }^{22}$

Dari hasil observasi dan wawancara yang telah peneliti lakukan di lapangan dapat dianalisis bahwa orang tua dalam membimbing anaknya harus ikut berperan penting dalam membina anaknya dikehidupan sehari-hari. Karena salah satu hal yang perlu diperhatikan dalam menciptakan masa depan anak adalah perlunya bimbingan dan penyuluhan melalui kegiatan-kegiatan yang bisa bermanfaat bagi perkembangan anak terkhusus bimbingan dalam pendidikan agama.

\section{Orang Tua Sebagai Pengawas}

Pengawasan itu penting sekali dalam mendidik anak. Tanpa pengawasan berarti membiarkan anak berbuat sekehendaknya anak tidak akan dapat membedakan yang baik dan yang buruk, tidak mengetahui yang mana sebaiknya dihindari atau tidak, mana yang boleh dan harus dilaksanakn serta yang mana membahayakan dan yang mana yang tidak membahayakan. ${ }^{23}$

Hal ini disampaikan oleh ibu Endang melalui wawancara yang peneliti lakukan, beliau mengatakan :

"Saya mengawasi anak saya dengan cara mengawasinya saat sedang belajar karena ketika belajar tidak diawasi anak saya suka malesmalesan dalam mengerjakan tugas sekolahnya dan saya juga mengawasi perilaku anak pada saat anak saya bermain serta saya menasihati anak

\footnotetext{
${ }^{21}$ Dilla, Anak Korban Keluarga Broken Home, Wawancara, 31 Agustus 2018

${ }^{22}$ Observasi Lapangan, Keluarga Broken Home Di Jalan Tanjung Rawo Rt 55 Rw 16 Kelurahan Bukit Lama Palembang, 2 Juli-23 Agustus 2018

${ }^{23}$ Ngalim Purwanto, Ilmu Pendidikan Teoritis Dan Praktis, (Bandung: Pt. Remaja Rosdakarya, 2011), Hlm. 179
} 
saya agar bermain di sekitaran rumah saat saya sedang bekerja sehingga pada saat saya pulang saya bisa mengontrol langsung anak saya tanpa harus mencarinya terlebih dahulu". ${ }^{24}$

Senada yang dikemukakan oleh ibu Endang, ibu Aci juga mengatakan :

"Ketika saya bekerja saya tidak bisa memberikan pengawasan pada anak karena ketika saya bekerja anak saya titipkan pada orang tua saya sehingga yang mengawasi anak saya ketika saya bekerja itu orang tua saya tetapi ketika saya pulang bekerja barulah saya bisa mengawasi perilaku anak saya, seperti cara dia bermain, berbicara dan cara dia mengatasi masalah saat dia sedang bertengkar pada temannya". ${ }^{25}$

Begitupun wawancara yang dilakukan oleh bapak Ninu, ia mengatakan :

"Saya bisa memberikan pengawasan anak saya pada saat saya mempunyai waktu luang atau tidak bekerja jika saya bekerja maka saya tidak bisa mengawasi perilaku anak saya setiap harinya". ${ }^{26}$

Berdasarkan hasil observasi yang peneliti lakukan di lapangan pada keluarga broken home di Jalan Tanjung Rawo Rt 55 Rw 16 Kelurahan Bukit Lama Palembang belum mampu mengawasi anak dengan baik karena kesibukan orang tua yang bekerja sehingga sedikit waktu dalam memberikan pengawasan pada anak tetapi walaupun orang tua yang sibuk dalam bekerja orang tua masih bisa memberikan pengawasan kepada anak saat orang tua pulang dalam bekerja. ${ }^{27}$

Dari hasil observasi dan wawancara yang telah peneliti lakukan di lapangan dapat dianalisis bahwa orang tua harus melakukan perannya sebagai pengawas dengan cara orang tua mengawasi tingkah laku anaknya tersebut baik di dalam bentuk belajar, ibadah dan lain-lain walaupun orang tua sibuk dalam bekerja tetapi orang tua masih bisa mengawasi anak dalam kehidupan sehari-hari setelah sepulang kerja.

\section{Orang Tua Sebagai Motivasi}

dalam mendidik anak perlu yang namanya motivasi untuk anak meningkatkan prestasi atau keinginan anak dalam mencapai suatu hal. Sebagai orang tua kita wajib untuk memotivasi anak ketika anak sedang mengalami kesulitan atau ketika anak sedang ingin menggapai suatu tujuan atau cita-cita yang hendak ia raihnya. Menurut Rohmalina Wahab, motivasi adalah keseluruhan dorongan, keinginan, kebutuhan,

\footnotetext{
${ }^{24}$ Endang, Orang Tua Yang Mengalami Keluarga Broken Home, Wawancara, 29 Agustus 2018

${ }^{25}$ Aci, Orang Tua Yang Mengalami Keluarga Broken Home, Wawancara, 27 Agustus 2018

${ }^{26}$ Ninu, Orang Tua Yang Mengalami Keluarga Broken Home, Wawancara, 2 September 2018

${ }^{27}$ Observasi Lapangan, Keluarga Broken Home Di Jalan Tanjung Rawo Rt 55 Rw 16 Kelurahan Bukit Lama Palembang, 2 Juli-23 Agustus 2018
} 
dan daya yang sejenis yeng mneggerakkan perilaku seseorang. Dalam arti luas, motivasi diartikan sebagai pengaruh dari energi dan arahan terhadap perilaku yang meliputi: kebutuhan, minat, sikap, keinginan, dan perangsang. ${ }^{28}$

Hal ini disampaikan oleh bapak Ninu melalui wawancara yang peneliti lakukan, beliau mengatakan :

"untuk memotivasi anak biasanya saya menjanjikan sebuah hadiah untuk anak ketika anak mendapatkan nilai yang bagus dari sekolah atau memotivasi dia saat dia sedang bermalas-malasan untuk tidak mau sekolah dengan alasan karena dia bertengkar dengan temannya sehingga dia takut untuk bersekolah tetapi saya sering memberikan nasihat atau dorongan untuk anak saya agar tidak takut dengan siapun dan harus menjadi anak yang pintar baik dalam pendidikan maupun di luar jalur pendidikan". ${ }^{29}$

Sama halnya yang dikemukakan oleh bapak Ninu, Neni anak bapak Ninu, mengatakan :

"bapak saya jika saya mendapatkan nilai yang bagus di sekolah bapak saya suka memberikan saya hadiah kepada saya agar saya bisa lebih giat lagi dalam belajar yang berupa seperti dibelikan tas sekolah dibelikan sepatu dan lain-lainnya tetapi bapak memberikan dengan catatan saya tidak boleh nakal di sekolah dan bermain dengan teman tidak boleh bertengkar serta harus mempertahan dan giat lagi dalam belajar dan sekolah tetapi bapak saya sering memarahi dan memukul saya ketika saya tidak mematuhi perkataannya". ${ }^{30}$

Begitupun ibu Lehak, mengatakan :

"biasanya saya memberikan hadiah kepada anak saya ketika dia mendapatkan nilai yang bagus disekolah atau mendapatkan prestasi dari sekolah, hadiah yang saya berikan berupa boneka atau penambahan uang jajan tetapi hadiah tersebut tidak saya lakukan terus menerus ketika ia mendapatkan prestasi di sekolah saya hanya sesekali saja memberikan hadiah agar anak saya lebih termotivasi dalam pendidikannya karenakan yang saya tau anak yang sudah ditinggalkan salah satu orang tuanya biasanya malas dalam segala hal baik belajar, sekolah dll maka dari itu untuk mengatasi tidak terjadinya hal tersebut saya selalu memberikan anak saya motivasi berupa ganjaran atau hadiah untuk anak saya". ${ }^{31}$

\footnotetext{
${ }^{28}$ Rohmalina Wahab, Psikologi Belajar, (Palembang: Grafika Telindo Press. 2015), Hlm.151 2018

${ }^{29}$ Ninu, Orang Tua Yang Mengalami Keluarga Broken Home, Wawancara, 2 September

${ }^{30}$ Neni, Anak Korban Keluarga Broken Home, Wawancara, 2 September 2018

${ }^{31}$ Lehak, Orang Tua Yang Mengalami Keluarga Broken Home, Wawancara, 31 Agustus 2018
} 
Lain halnya yang dikemukaan dari ketiga informan di atas, ibu Elly mengatakan :

"saya memberikan motivasi pada anak saya ialah dengan cara menasehatinya saya tidak pernah menjanjikan sesuatu hadiah untuk anak-anak saya karena kenapa saya hanya memberikan motivasi lewat ucapakan karena saya tidak ingin membiasakan anak saya untuk mendapat suatu imbalan dari sebuah prestasi yang ia lakukan menurut saya itu membuat anak malah menjadi melakukan sesuatu yang tidak ikhlas yang tidak dengan hatinya sehingga ketika saya ada uang lebih maka tidak harus menunggu anak saya mendapatkan prestasi di sekolah saya bisa memberikan hadiah untuk nya tapi sebaliknya ketika dia melakukan kesalahan maka saya tetap menghukumnya, memukulnya, dan memarahinya. Hukuman tang biasa saya lakukan untuk anak saya agar dia jera ialah tidak dikasih uang jajan selama 3 hari". ${ }^{32}$

Berdasarkan hasil observasi yang peneliti lakukan di lapangan pada keluarga broken home di Jalan Tanjung Rawo Rt 55 Rw 16 Kelurahan Bukit Lama Palembang cara orang tua memotivasi anak ialah dengan cara menasihati anak dan mengarahkan anak dengan perilaku yang baik-baik dan memberikan hukuman apabila anak melanggar hal yang tidak boleh dilakukan oleh orang tua serta mendapatkan ganjaran berupa hadiah untuk anak ketika anak mendapatkan nilai yang bagus dari sekolah. ${ }^{33}$

Dari hasil observasi dan wawancara di atas dapat dianalisi bahwa upaya orang tua dalam meunumbuhkan motivasi anak adalah upaya orang tua agar anak-anak maju sesuai bakat, kemampuan, dan kepribadian. Dengan demikian anak akan berkembang secara optimal dan tidak melanggar aturan-aturan yang ada di dalam lingkungan masyarakat.

\section{KESIMPULAN}

Berdasarkan analisis penelitian yang peneliti lakukan dilapangan dengan teori yang ada, maka dapat diambil kesimpulan sebagai peran pendidikan In-formal dalam mendidik anak pada keluarga broken home di Jalan Tanjung Rawo Rt 55 Rw 16 Kelurahan Bukit Lama Palembang ialah, orang tua sebagai suri tauladan yang baik, orang tua sebagai pendidik, orang tua sebagai pembimbing, orang tua sebagai pengawas, dan orang tua sebagai motivasi

\footnotetext{
${ }^{32}$ Elly, Orang Tua Yang Mengalami Keluarga Broken Home, Wawancara, 25 Agustus 2018

${ }^{33}$ Observasi Lapangan, Keluarga Broken Home Di Jalan Tanjung Rawo Rt 55 Rw 16 Kelurahan Bukit Lama Palembang, 2 Juli-23 Agustus 2018
} 


\section{DAFTAR PUSTAKA}

Ahmadi Abu, 2009. Psikologi Sosial. Jakarta: PT Rineka Cipta.

Rusmaini, 2014. Ilmu Pendidikan. Palembang: Grafika Telindo Press

Syaiful Bahri Djamarah. 2014Pola Asuh Orang Tua Dan Komunikasi Keluarga. Jakarta:Rineka Cipta,

Djamarah, Syaiful Bahri. 2014. Pola Asuh Orang Tua Dan Komunikasi Keluarga. Jakarta:Rineka Cipta

Syarbini, Amirulloh. 2014. Model Pendidikan Karakter Dalam Keluarga, (Jakarta: Pt. Elex Media Komputindo.

Sri Lestari, Psikologi Keluarga, (Jakarta: Kencana, 2012), Hlm. 162

Aci, Orang Tua Yang Mengalami Keluarga Broken Home, Wawancara, 27 Agustus 2018

Elly, Orang Tua Yang Mengalami Keluarga Broken Home, Wawancara, 25 Agustus 2018

Lehak, Orang Tua Yang Mengalami Keluarga Broken Home, Wawancara, 31 Agustus 2018

Jaya, Anak Korban Keluarga Broken Home, Wawancara, 27-28 Agustus 2018

Anharrudin, Anak Korban Keluarga Broken Home, Wawancara, 26 Agustus 2018

Observasi Lapangan, Keluarga Broken Home Di Jalan Tanjung Rawo Rt 55 Rw 16 Kelurahan Bukit Lama Palembang, 2 Juli-23 Agustus 2018

Ridwan Abdullah Sani Dan Muhammad Kadri, Pendidikan Karakter, (Jakarta: PT. Bumi Aksara, 2016), Hlm. 212

Elly, Orang Tua Yang Mengalami Keluarga Broken Home, Wawancara, 25 Agustus 2018

Lehak, Orang Tua Yang Mengalami Keluarga Broken Home, Wawancara, 31 Agustus 2018

Dilla, Anak Korban Keluarga Broken Home, Wawancara, 31 Agustus 2018

Observasi Lapangan, Keluarga Broken Home Di Jalan Tanjung Rawo Rt 55 Rw 16 Kelurahan Bukit Lama Palembang, 2 Juli-23 Agustus 2018

Chairinniza Graha, Keberhasilan Anak Tergantung Orang Tua, (Jakarta: Pt. Elex Media Komputindo, 2007), Hlm. 98

Ninu, Orang Tua Yang Mengalami Keluarga Broken Home, Wawancara, 2 September 2018

Aci, Orang Tua Yang Mengalami Keluarga Broken Home, Wawancara, 27 Agustus 2018

Lehak, Orang Tua Yang Mengalami Keluarga Broken Home, Wawancara, 31 Agustus 2018

Dilla, Anak Korban Keluarga Broken Home, Wawancara, 31 Agustus 2018

Observasi Lapangan, Keluarga Broken Home Di Jalan Tanjung Rawo Rt 55 Rw 16 Kelurahan Bukit Lama Palembang, 2 Juli-23 Agustus 2018

Ngalim Purwanto, Ilmu Pendidikan Teoritis Dan Praktis, (Bandung: Pt. Remaja Rosdakarya, 2011), Hlm. 179 
Endang, Orang Tua Yang Mengalami Keluarga Broken Home, Wawancara, 29 Agustus 2018

Aci, Orang Tua Yang Mengalami Keluarga Broken Home, Wawancara, 27 Agustus 2018

Ninu, Orang Tua Yang Mengalami Keluarga Broken Home, Wawancara, 2 September 2018

Observasi Lapangan, Keluarga Broken Home Di Jalan Tanjung Rawo Rt 55 Rw 16 Kelurahan Bukit Lama Palembang, 2 Juli-23 Agustus 2018

Rohmalina Wahab, Psikologi Belajar, (Palembang: Grafika Telindo Press. 2015),

Ninu, Orang Tua Yang Mengalami Keluarga Broken Home, Wawancara, 2 September 2018

Neni, Anak Korban Keluarga Broken Home, Wawancara, 2 September 2018

Lehak, Orang Tua Yang Mengalami Keluarga Broken Home, Wawancara, 31 Agustus 2018

Elly, Orang Tua Yang Mengalami Keluarga Broken Home, Wawancara, 25 Agustus 2018

Observasi Lapangan, Keluarga Broken Home Di Jalan Tanjung Rawo Rt 55 Rw 16 Kelurahan Bukit Lama Palembang, 2 Juli-23 Agustus 2018 